\author{
Andrzej Lemański \\ Uniwersytet SWPS \\ (iD https://orcid.org/0000-0003-0093-9408
}

\title{
Automatyzacja pracy a zmiany na rynku pracy Czy, a jeśli tak, to w jaki sposób mierzyć pracę umysłową i poziom jej automatyzacji
}

\begin{abstract}
The main aim of the article is to establish if and how we can research the impact of automation of work on the labour market. In this paper, I discuss measurement issues of automation of work with theoretical and statistical parts including elements of methodology. The text begins by discussing the dependences between physical and cognitive work and pays attention to the theoretical and historical sources of this division. Then, I point out hybrid forms of cognitive work as a result of the progressing digitalization, which leads me to the indication of big data and algorithms as one of the most important elements of modern work automation. The foregoing prompts the following question: If we take into account the prospective hybridization of machines and humans, should we still measure the cognitive work, especially in its quality dimensions? Finally, I provide examples of some possible methods of measurement of the automation of cognitive work, especially by pointing out selected changes which automation introduces into the labour market.
\end{abstract}

Key words: automation of work, cognitive work, sociology of work, labour market

\section{Praca umysłowa a praca fizyczna}

Automatyzacja pracy umysłowej to temat, który rodzi się na naszych oczach. Według raportu „Global Human Trends 2017” 41\% dyrektorów wykonawczych przebadanych przez firmę Deloitte potwierdziło, że wdrożyło już lub kończy wdrażać technologię sztucznej inteligencji współpracującej z ludzkimi pracownikami. Kolejne 34\% respondentów zadeklarowało, że w ich korporacjach trwają stosowne 
programy pilotażowe (Schwartz i in., 2017). Według badań z grudnia 2017 roku tylko w Stanach Zjednoczonych roczna liczba patentów związanych z automatyzacją wzrosła z 70 tysięcy w roku 1976 do 180 tysięcy w roku 2014. Oznacza, to że 40 lat temu w Stanach co czwarty patent dotyczył automatyzacji, dzisiaj zaś co czwarty jej nie dotyczy (Mann, Püttmann, 2017).

Praktyk automatyzowania czynności umysłowych należy dopatrywać się co najmniej od czasów wynalezienia technologii pisma, potem druku i biurokracji, aż po czasy komputeryzacji w USA w latach 60., które stanowią łącznik do współczesności. Trzeba przy tym zaznaczyć, że wśród badaczy nie ma zgodności co do tego, czy umaszynowienie (a potem automatyzacja) pracy umysłowej postępowało wraz z umaszynowieniem (oraz automatyzacją) pracy fizycznej. Większość z nich chciałaby widzieć proces postępującej mechanizacji pracy etapami. Od automatyzacji prostych czynności fizycznych w okresie przed industrializacją, następnie poprzez umaszynowienie pracy w okresie industrializacji, aż po współczesne społeczeństwo informacyjne, gdzie automatyzuje się już głównie pracę umysłową. Kiedy badamy proponowane przez różnych autorów opisy kolejnych etapów umaszynowienia pracy, możemy zwrócić uwagę na ciągłość myśli, które opowiadają o procesach uprzemysłowienia i/lub informacjonalizacji różnych typów społeczeństwa (określanych jako rolnicze, industrialne, informacyjne). Zarówno Manuel Castells (2007) oraz James Beniger (1986), jak i historyk zajmujący się rozwojem społeczno-gospodarczym narodów David S. Landes (2000) płynnie przechodzą od industrializacji do komputeryzacji społeczeństwa. Wskazują na ten sam trend umaszynowienia pracy, ale dochodzą do zupełnie odmiennych wniosków, gdy mowa o konsekwencjach w zależności od opisywanej formacji społeczno-gospodarczej.

Z kolei Marshall McLuhan widzi cywilizacyjne dzieje zupełnie inaczej. Wskazuje na technologie jako kolejne formy przedłużeń wspomagających ludzkie zmysły i potencjał umysłowy (McLuhan, 2004). Wśród najważniejszych technologii w historii dziejów wymienia pismo i druk. Jeśli zaś chodzi o współczesność, to McLuhan skupił swoją uwagę na telewizji. Chociaż on także podzielił koleje cywilizacji według własnej koncepcji na epoki: plemienną, pisma oraz elektryczną, to jednak głosił, że w każdej z nich technologie umysłowe odgrywały rolę kluczową. Zupełnie inaczej widział to wspomniany wcześniej Landes. Doszukując się źródeł bogactwa narodów opisywał trend umaszynowienia pracy, który w jego odczuciu był od wielu wieków najważniejszą formą oszczędności czasu i energii. Najpierw była to oszczędność energii fizycznej, wydatkowanej przez mięśnie ludzi i zwierząt. Następnie zaś wprowadzane stopniowo maszyny (komputery, oprogramowanie) miały na celu oszczędzanie energii intelektualnej (kognitywnej) lub — jakby to ujął McLuhan — zwielokrotnienie owej energii, którą nosi w sobie każdy z nas.

Korzystając ze słownika cybernetyki możemy powiedzieć, że podejście klasycznych badaczy dziejów opierało się na schemacie, w ramach którego splot energii, informacji oraz materii zmieniał swoje proporcje w zależności od epoki dziejowej. Im bliżej współczesności, tym mniej zużywamy w procesie pracy energii fizycznej

14 na rzecz coraz większego zaangażowania energii kognitywnej (de Kerckhove, 
2009). Z tym wiąże się fakt, że materia, którą produkujemy, zawiera w sobie coraz więcej informacji, np. w formie wykonywalnego kodu programistycznego. Dlatego można dojść do prostego wniosku, że podział na pracę umysłową i fizyczną nigdy nie był do końca trafny, gdy przychodziło do praktyki codziennej pracy, szczególnie w społeczeństwie informacjonalistycznym. Początków podziału na pracę umysłową i fizyczną można już szukać w myśli św. Tomasza, na którą powoływał się między innymi Władysław Jacher. Wskazywał on, że już wtedy akcentowano wyższość pracy umysłowej nad fizyczną. Natomiast św. Tomasz zwracał uwagę na element integralności obu rodzajów pracy — praca fizyczna musiała zawierać elementy umysłowe, zaś praca umysłowa męczyła fizycznie (Mariański, 2015). To fundament rozumienia psychofizycznej natury człowieka.

Aby jakaś czynność mogła być nazwana pracą, musi nieść za sobą efekt w postaci dobra - ekonomicznego czy też społecznego. Tadeusz Kotarbiński stwierdza z kolei, że praca powinna rozwiązywać lub dążyć do rozwiązania jakiegoś istotnego problemu (społecznego), co pokrywa się z definicją dobra społecznego. Przyjmijmy więc, że czynność, którą nazywamy pracą, musi mieć swój cel. Praca umysłowa może być podzielona według następującego schematu:

- Praca umysłowa z efektami materialnymi - istotne jest, aby przy produkcji jakiegoś dobra wartość komponentu niefizycznego (intelektualnego lub zmysłowego) przewyższała wartość wszystkich użytych komponentów fizycznych. Może to być na przykład praca technika polegająca na zaprogramowaniu podzespołu elektronicznego samego w sobie praktycznie pozbawionego wartości. Warto pamiętać, że każdy produkt materialny zawiera w sobie komponent niematerialny w postaci mniej lub bardziej zaawansowanej myśli technicznej. $Z$ reguły im bardziej zaawansowany technologicznie produkt, tym jest prostszy w obsłudze w stosunku do funkcjonalności, którą oferuje.

- Praca umyslowa z efektami niematerialnymi - polega na obróbce danych i informacji, a jej efektem wyjściowym są również dane i informacje. W idealnej sytuacji efektem końcowym pracy niematerialnej powinna być wiedza, ale to zbyt wąsko zakrojona definicja, gdyż nie obejmuje szeregu czynności związanych z rutynowymi pracami umysłowymi, których efektem często jest półprodukt podlegający dalszej obróbce. Jest to uwaga szczególnie istotna, gdy analizujemy działanie automatów wykonujących pracę umysłową. Efekty pracy niematerialnej to także produkty sprzedawane przez przemysły kultury i wiedzy, a więc wytwór pracy nierutynowej, opartej na myśleniu abstrakcyjnym i jakościowym. Tego typu produkty pracy dostarczają doznań, emocji i przeżyć. Jak zauważa Kazimierz Krzysztofek, konsumpcja niematerialna nastawiona jest na twórczość, podnoszenie jakości życia. Realizowana jest w ramach refleksyjnego projektu życiowego, w ramach którego istotną rolę odgrywają przyroda i kultura, zaś ,zwiększanie się puli pracy niematerialnej związane jest z dematerializacją gospodarki" (Krzysztofek, 2012).

- Praca umysłowa nakierowana na budowanie relacji społecznych - tego typu praca głównie w sektorze usług to najdynamiczniej rosnący sektor zatrudnienia w gospodarkach rozwiniętych. Dotyczy na przykład medycyny i edukacji, gdzie 
rośnie zapotrzebowanie na pracę opartą na zawiązywaniu i podtrzymywaniu relacji z innymi ludźmi w wyniku realizowania usług, takich jak opieka nad chorym albo opieka nad rozwojem intelektualnym czy ogólniej osobistym (couching, tutoring, mentoring itd).

Mając na uwadze przedstawione rozważania, w niniejszym tekście będę zajmował się wyłącznie pracą umysłową z efektami niematerialnymi. Wynika to $\mathrm{z}$ konieczności zawężenia tematu, tak aby móc wskazać konkretne przypadki wpływu automatyzacji pracy na rynek pracy.

Kolejnym elementem składającym się na pracę umysłową jest narzędzie, za pomocą którego praca jest wykonywana. W przypadku społeczeństwa informacyjnego tym narzędziem jest forma komputera - smartfon, tablet, laptop, desktop. Jednak tym, co odróżnia epokę przedinformacyjną od epoki informacyjnej, jest fakt zastosowania narzędzi, które są programowalne - mają system operacyjny i interfejs. Ich możliwości są skalowalne dzięki oprogramowaniu. Przyjmijmy więc, że narzędziem pracy niematerialnej nie jest maszyna licząca, lecz oprogramowanie - od arkusza kalkulacyjnego i bloga Wordpress aż po programy graficzne, jak Photoshop, czy też wspomagające projektowanie (CAD). Wysiłek to kolejny wspominany już wcześniej element, jaki pojawia się podczas wykonywania pracy. Innymi słowy, mamy tu do czynienia z energią — fizyczną i mentalną. $\mathrm{O}$ ile zużycie energii fizycznej jest minimalne, o tyle w przypadku pracy niematerialnej mamy do czynienia ze znacznym zużyciem energii mentalnej czy — jak nazywa ją Derrick de Kerckhove - energii kognitywnej (de Kerckhove, 2009).

Definiując pracę umysłową, której efektem są dobra niematerialne, należy uwzględnić następujące komponenty:

- cel, jakim jest produkcja dobra ekonomicznego lub społecznego czy też celowa czynność społecznie użyteczna/doniosła;

- narzędzie, czyli oprogramowanie;

- przedmiot pracy, czyli dane, informacja, wiedza;

- wysiłek, czyli energia kognitywna oraz energia fizyczna.

\section{Hybryda pracy ludzkiej i maszynowej}

Na mieszankę pracy umysłowej i fizycznej nakłada się połączenie pracy ludzi i pracy maszyn, które wymaga osobnego krótkiego omówienia. Sam zwrot „praca maszyn" jest tu postawiony jako przeciwieństwo zwrotu ,praca ludzka” i nie powinien być wiązany wyłącznie z erą industrialną. Praca maszyn to praca pochodzenia „sztucznego", nie ludzkiego, jak powiedziałby Bruno Latour. To ostre rozgraniczenie pojęć nie jest próbą przedstawiania czarno-białej rzeczywistości, ale jedynie przygotowaniem stosownego narzędzia pracy do dalszych rozważań. Trzeba przy tym pamiętać, że praca ludzi i maszyn zachodzi zawsze w określonej relacji. W najprostszym ujęciu jest to kooperacja lub konkurencja (Lemański, 2015). 
Konkurencja winna skutkować zjawiskiem, które John Maynard Keynes określił mianem bezrobocia technologicznego (Keynes, 1930). Jego wypowiedź sprzed blisko stu lat w dalszym ciągu wywiera olbrzymi wpływ na nasze rozumienie relacji ludzi i maszyn. Z kolei kooperacja maszyn i ludzi jest zdecydowanie gorzej przebadanym w ujęciu ekonomicznym problemem, podejmowanym raczej w ramach dziedzin związanych z ogólnie rozumianą filozofią i socjologią nowoczesnych technologii, np. wspomnianą wcześniej teorią mediów McLuhana czy Actor-Network Theory Bruno Latoura i Johna Lawa. Jednocześnie najważniejszym nurtem, który podejmuje ogólnie pojętą problematykę relacji człowiek - maszyna pozostaje STS (Science Technology Studies) z licznymi rozgałęzieniami, np. SCOT (Social Construction of Technology) autorstwa Trevora Pincha i Wiebe'a E. Bijkera (zob. więcej Pinch, Bijker, 1993). Przy czym dzieje się to w szeroko zakrojonych badaniach relacji społeczeństwo-technologia, zazwyczaj o wymiarze jakościowym. Kolejną płaszczyzną, na której można rozpatrywać relacje maszyn i ludzi, jest bipolarne zestawienie determinizmu technologicznego i konstruktywizmu społecznego (zob. więcej Szpunar, 2012).

Patrząc na relacje maszyn i ludzi na rynku pracy z punktu widzenia determinizmu technologicznego można powiedzieć, że automatyzacja pracy wymusiła, wymusza i będzie wymuszać zmianę struktury czynności z rutynowych na nierutynowe w ramach większości zawodów. Konstruktywizm społeczny wskazywałby z kolei, że przedsiębiorstwa kierowane naukowym zarządzaniem dzielą zawody na zbiór elementarnych czynności (tayloryzm), co od dawna przygotowało je na wynalazki, takie jak automaty wykonujące rutynowe czynności. Nie ma więc tutaj mowy o determinizmie ze strony technologii, lecz jedynie o sekwencji wydarzeń, gdy na podatny już społecznie grunt wchodzą i są wdrażane oczekiwane od dawna wynalazki. Konsekwencje zaś są od dawna znane, przynajmniej w skali pojedynczych zawodów. Nie jest celem tego tekstu roztrząsanie sporu między tymi dwoma poglądami naukowymi. Najbliższy prawdy wydaje się Manuel Castells, który stwierdza, że technika nie determinuje społeczeństwa. Poza tym ,społeczeństwo nie pisze scenariusza zmiany technologicznej, ponieważ w proces odkryć naukowych, technicznych innowacji i społecznych zastosowań interweniuje wiele czynników, włączając w to indywidualną pomysłowość i przedsiębiorczość, tak że końcowy wynik zależy od złożonego wzoru interakcji” (Castells, 2007, s. 22-23).

W nurt konstruktywizmu społecznego oraz kooperacji maszyn i ludzi wpisuje się ideologia transhumanizmu z jej wizją ludzi wspieranych przez sztuczną inteligencję. Chociaż jest to wizja daleka od ziszczenia się w formie, w jakiej widzą ją pisarze fantastyki naukowej, to zawiera w sobie esencję omawianego zagadnienia: człowiek plus wzmocnienia, a mówiąc za McLuhanem — przedłużenia jego zmysłów i siły intelektu. To wszystko prowadzi nas do wizji dzisiejszej pracy umysłowej, która składa się z dwóch nierozdzielnych komponentów: pracy ludzkiej oraz pracy maszynowej (w tym pracy automatów).

Dotychczas hybrydyzacja pracy umysłowej ludzi i maszyn przebiegała na co najmniej trzech ogólnych wzajemnie uzupełniających się poziomach: obliczeń, komunikacji oraz retencji danych. We wszystkich tych dziedzinach komputery 
wydatnie zmieniły możliwości organizacji biznesowych i instytucji państwowych. Oprogramowanie sprawiło, że ludzie zyskali nieograniczoną ilość pamięci, mogąc kontaktować się praktycznie z dowolną osobą na świecie, w dowolnym momencie, zaś moc obliczeniowa jest na wyciągnięcie ręki, w usłudze chmury, w cenie już od kilku dolarów miesięcznie.

Skoro o narzędziach mowa, to na marginesie rozważań o hybrydyzacji maszyn i ludzi trzeba nadmienić, że tak jak różna jest jakość pracy ludzkiej, tak różna może być jakość pracy komponentu maszynowego. Na ową jakość składa się zarówno „mądrość” i funkcjonalność narzędzia, jak i kwalifikacje operatora i programisty. Dlatego skazane są na porażkę rozważania o tym, czy człowiek jest tu stroną pasywną, z powodu pełnienia tylko funkcji kontrolnej nad maszyną, która posiada wewnętrzny algorytm, jak chciałby widzieć to na przykład Villem Flusser (zob. więcej Flusser, 2015), czy też aktywną, z powodu wewnętrznej internalizacji narzędzi pracy $\mathrm{w}$ formie pracy żywej (zob. więcej Pasquinelli, 2011). Model hybrydowej pracy zdaje się dobrze opisany w koncepcji nazwanej Teoria Aktora-Sieci, gdzie w nieprzerwanym cyklu interakcji narzędzie i podmiot ludzki wzajemnie rekonfigurują się w nieskończoność. Przy czym im lepiej wykształcony pracownik, tym większe są jego możliwości operowania narzędziem oraz większe możliwości awansu na drabinie zawodowej. Zwracają na to uwage autorzy raportu $\mathrm{PwC}$ „Confidence in the Future Human and Machine Collaboration in the Audit”, konstatując, że przyszłością audytu jest ścisła kooperacja pracowników otoczonych przydatnymi maszynami, które zaoferują zupełnie nowe funkcje poznawcze, niemożliwe do zrealizowania dotychczas z powodu naturalnych ludzkich ograniczeń.

Shoshana Zuboff analizując problem big data w organizacjach wskazała na dylemat, jaki rodzi się podczas współpracy maszyn i ludzi we współczesnym przedsiębiorstwie opartym na pracy umysłowej. Według Zuboff najbardziej prawdopodobne są dwa scenariusze. W pierwszym z nich ludzcy pracownicy zostaną zepchnięci na peryferia procesów pracy, zaś centralną rolę będą pełnić tzw. smart machines, nad którymi kontrolę sprawuje elita programująca algorytmy, i narzucające agendę poprzez system zarządzania przedsiębiorstwem. W drugim, opozycyjnym, inicjatywę przejmą tzw. smart people otoczeni maszynami, które będą obserwować pracę najlepszych z nich, analizować ją i wykorzystywać pozyskane informacje do optymalizacji pracy pozostałych. Tym samym smart machines, jak nazywa Zuboff ,inteligentne” systemy komputerowe, będą wspierać pozycję zawodową i podmiotowość pracowników (Zuboff, 2001, s. 9).

Pierwszy scenariusz wróży także Brian Arthur, twórca pojęcia second econo$m y$, które trafnie opisuje świat pracy cyfrowych maszyn spiętych siecią Internet jako zupełnie oddzielny obieg informacyjny, aktualizujący się miliony razy na sekundę poza świadomością przeciętnego człowieka (A r thur, 2011). Jak twierdzi Arthur, nowa gospodarka będzie opierała się na gig economy realizowanym już nie przez ludzi, ale przez gotowe algorytmy komputerowe przystosowane do wykonywania określonych czynności. Z jednej strony będziemy mieli korporacje,

18 które będą przygotowywały biblioteki gotowych funkcjonalności zalgorytmizo- 
wanej w oprogramowaniu pracy umysłowej, z drugiej zaś korporacje, które będą nabywały abonamentowy dostęp do nich, a więc będzie to offshoring w wydaniu wirtualnym.

Podsumowując omawianie hybrydyzacji pracy umysłowej ludzi i maszyn, można wskazać co najmniej trzy zasadnicze kierunki rozwoju relacji (przy czym nie są to relacje wyłączne):

- maszyna zastępuje człowieka,

- maszyna pomaga człowiekowi,

- maszyna wykonuje pracę niemożliwą do wykonania przez człowieka.

Można stąd wyciągnąć wniosek, że zarówno współczesne zawody, jak i struktura zakładów pracy są w znacznym stopniu definiowane przez maszyny, jakich używa się do produkcji materialnej i niematerialnej. Można by tę myśl rozszerzyć mówiąc, że im więcej wynalazków, tym więcej nowych miejsc pracy i nowych zawodów. A to oznacza coraz szybsze zmiany w strukturze zawodów i coraz mniejszą możliwość predykcji, jakie zawody przetrwają kolejne dekady, jakie powstaną, a jakie poddadzą się procesowi automatyzacji. Takie rozumowanie wskazuje na zachowanie wysokiego poziomu ostrożności w osądzaniu, w jak dużym stopniu automaty odbiorą ludziom miejsca pracy. Mówiąc metaforycznie, gdy maszyny przyjdą po naszą pracę, może się okazać, że nikomu nie są już potrzebne jej owoce. Takie są efekty błyskawicznie zmieniających się gustów konsumenckich, które także mają swój udział w zmianie struktury zawodowej.

\section{Praca automatów}

Podana w słowniku PWN etymologia słowa „automatyzacja” wywodzi się od greckiego wyrazu automatos, oznaczającego ‘samoczynny'. Czas, w którym narodziło się to pojęcie nie jest przypadkowy. Starożytni Grecy mieli głęboką intuicję, która wyrażała się w opisywanych przez Homera samodzielnie poruszających się maszynach zdolnych mówić. Miał je wykuwać Hefajstos w swojej kuźni na dnie Etny. Owa ,samoczynność” jest tu pojęciem kluczowym, które pozwala odróżnić pracę maszynową od pracy automatycznej. Ogólnie automatyzację pracy umysłowej można rozumieć na dwa sposoby:

1) jako pakiet kilku czy kilkunastu czynności (algorytmów), które pozwalają wypełnić określone zadanie, a więc w całości zastąpić człowieka w określonej funkcji - człowiek jest tylko operatorem uruchamiającym proces i kontrolerem jego przebiegu;

2) jako prosty algorytm wykonujący nawet jedną czynność, np. arkusz kalkulacyjny z funkcjami obliczeniowymi czy też kalkulator, przy czym człowiek musi pozostać aktywną stroną, która uczestnicy w procesie wykonania zadania, gdyż użycie jednego algorytmu (a nie zespołu algorytmów) nie pozwala na zautomatyzowanie całego zadania. 
Biorąc pod uwagę oba warianty przyjmuję definicję automatyzacji pracy jako: wszelkie czynności wykonywane przez maszynę samodzielnie, które wcześniej w zbliżonej formie były lub mogłyby być wykonywane przez czlowieka, oraz te, które są zbyt trudne do wykonywania przez czlowieka. W ramach automatyzacji pracy czlowiek pelni funkcję nadzorczą i kontrolną w stosunku do maszyny i jej pracy. Automatyzacja pracy może obejmować zarówno cały proces wytworzenia, jak i jego pojedyncze etapy, które mogą być uzupelniane pracą ludzką. Mówiąc w skrócie: skłaniam się ku pierwszemu, bardziej rozbudowanemu rozumieniu automatyzacji pracy. Definicja ta jest o tyle istotna, że jak dotychczas nie udało mi się odnaleźć w polskiej literaturze przedmiotu wprost zdefiniowanej automatyzacji pracy umysłowej. Opis ten koresponduje z innym terminem, zastosowanym przez autorów badań, w ramach których sprawdzano wpływ stosowania patentów automatyzacji pracy na zatrudnienie w Stanach Zjednoczonych: ,patent dotyczący automatyzacji opisuje urządzenie, które operuje niezależnie od ludzkiego działania i wypełnia względnie całościowe zadania" (Mann, Püttmann, 2017).

Jak wspomniano, z punktu widzenia obserwatora tym, co czyni maszynę automatem, jest jej „samoczynność”. Źródła samoczynności automatu umysłowego (komputera i oprogramowania) starannie omawia Pasquinelli. Zawartość wsadu pracy żywej (jednostkowej pracy człowieka) definiuje, czy mamy do czynienia z narzędziem, czy z maszyną, oraz co ważne - z jaką formą maszyny. Zacznijmy od pierwszego przypadku. Otóż, jeśli mamy do czynienia z narzędziem (a nie maszyną), wsad pracy żywej ogranicza się zdaniem Pasquinelliego do energii. I jest to zasadnicza różnica w odniesieniu do maszyny, ponieważ czy to mowa o maszynie ery przemysłowej, czy o maszynie Turinga poza wsadem energetycznym niezbędny jest wsad informacyjny ze strony pracy żywej. Trzeba tu zastrzec, że w maszynie zawarty jest już wsad pracy żywej w formie pracy martwej, a więc wykonanej wcześniej intelektualnej pracy ludzkiej przekształconej w środek trwały (maszynę, czyli kapitał). Innymi słowy - jest to wiedza naukowa oraz wiedza społeczna (całość tego Marks określa mianem intelektu powszechnego „General Intellect”), jaka była niezbędna do takiego, a nie innego zaprojektowania maszyny. Wiedza ta zawarta jest już w maszynie, jej strukturze, w formie działania w terminologii neomarksistowskiej staje się pracą martwą (Pa squinelli, 2011).

Gdy myślimy o prostym mechanicznym narzędziu, algorytm kryje się w głowie wykonawcy pracy żywej, czyli pracownika, i tym samym nigdy nie jest dostarczany do wnętrza narzędzia. Narzędzie wymaga wysokich kwalifikacji rzemieślniczych, wiedzy o całym procesie produkcji, maszyna wręcz przeciwnie, co bierze swoje źródło w podziale pracy - taka jest esencja rozróżnienia Pasquinelliego. Podobna sytuacja ma miejsce w przypadku oprogramowania automatyzującego pracę umysłową. Praca żywa, czyli zaszyte algorytmy postępowania wymyślone i utrwalone w procesie pracy ludzkiej, zostają przeniesione do kodu źródłowego oprogramowania, gdzie stają się pracą martwą. Jak zauważa Pasquinelli, podział pracy jest fundamentem mechanizacji oraz automatyzacji, a proces ten stanowi aktualnie najważniejsze źródło kapitalizmu kognitywnego. Jego głównym elementem jest 
wzbierająca ilość wiedzy martwej zamkniętej w maszynach, która nieustannie powiększa wartość środków trwałych. Zgodnie z potocznym myśleniem - im bardziej inteligentna maszyna, tym bardziej automatyczna, czyli samodzielna, a ilość zawartego w niej kapitału pracy martwej staje się jeszcze większa.

\section{Big data jako źródło automatyzacji pracy}

Aby komputery mogły osiągnąć pozycję niezastąpionych narzędzi, a zdaniem niektórych - nawet partnerów ludzi w pracy umysłowej, musiała się dokonać rewolucja digitalizacji otaczającego nas świata. Komputery zostały pomyślane jako maszyny służące stricte do obliczeń. Z czasem w latach 90 . XX wieku rozwój technologii komunikacyjnych oraz sensorycznych sprawił, że użytkownicy pecetów zaczęli boleśnie odczuwać brak miejsca na dyskach twardych, zaś domowe łącza internetowe, niegdyś tylko dla wybranych, z czasem coraz popularniejsze, zapchały się na dobre. Nie bez powodu właśnie w tym okresie narodził się termin big data, który prawdopodobnie po raz pierwszy w publikacji naukowej pojawił się stosunkowo późno, bo w 1998 roku, w artykule Weissa i Indukhya zatytułowanym Predictive Data Mining. A practical guide. Postępująca od dekad cyfryzacja i rozwój prac nad algorytmami komputerowymi w ostatnich dwudziestu latach sprawiły, że stopniowo ujawniały się nowe wymiary pracy umysłowej, w których ludzie mogli z czasem liczyć na pomoc maszyn w formie:

- kopiowania treści,

- generowania treści,

- ewaluacji treści,

— decyzyjności,

- predykcji,

- wnioskowania.

Przykładowe branże, które już dziś stosują algorytmy, to: bankowość, giełda, medycyna, prasa, media społecznościowe czy handel internetowy. Najbardziej znanym przedstawicielem nowej ligi automatów jest Watson - skomplikowany zespół algorytmów zdolnych do rozumienia naturalnego języka, uczący się na podstawie informacji z Internetu, zdolny do przetwarzania terabajtów informacji w bardzo krótkim czasie na konkretne wnioski zrozumiałe dla ludzi. Projekt w pewnym sensie sztucznej inteligencji stworzony w ramach IBM-owskiego programu DeepQuestionAnswering okazał się faktyczną innowacją. Watson był zdolny do konkurowania z ludźmi w ramach jednego z najsłynniejszych programów telewizyjnych „Jeopardy!”. Co więcej, wygrał!

Z kolei Watson for Oncology to jedna z wersji przygotowana do wspomagania leczenia pacjentów z nowotworami. Przygotowano ją we współpracy ze specjalistami z Memorial Sloan-Kettering Cancer Center w Nowym Jorku. Watson „uczył się” z blisko 300 czasopism i książek oraz 12 milionów stron tekstów dotyczących nowo- 
tworów. W tej chwili stosowany jest w sieci szpitali Manipal Hospitals w Indiach i dzięki jego wsparciu leczonych jest ponad 200 tysięcy pacjentów w 16 placówkach na terenie Indii. Coraz powszechniej stosowane są także tzw. software robots, które nazywam botami programowymi.

Czym jest bot programowy? To zespół algorytmów, których zadaniem jest wykonywanie prostych czynności na oprogramowaniu komputera. Jakkolwiek zawile to brzmi, sprawa jest prosta: software robot to bot, który obsługuje komputer tak, jak robi to pracownik biurowy. Taki bot może na przykład: przeklejać dane z rubryk w arkuszu kalkulacyjnym do bazy danych innego oprogramowania, czytać formularze za pomocą technologii OCR oraz wprowadzać dane z rubryk do pól w oprogramowaniu systemu. Co więcej, bot może korzystać z zewnętrznych peryferii kontrolując ruchy kursora na ekranie i wypełniając pola systemu „klawisz po klawiszu”, „klik po kliku”. Dzięki temu bot może współpracować z dowolnym oprogramowaniem, wystarczy ,nauczyć” go obsługi, tzn. zaprogramować czynności, które ma wykonywać w określonej sekwencji.

To pokazuje, że powoli, ale konsekwentnie projektanci szeroko pojętej sztucznej inteligencji mogą uporać się z paradoksem Moraveca, który głosi, że łatwo jest nauczyć komputer rozwiązać proste logiczne zagadki, ale praktycznie niemożliwe jest zmuszenie go do tego, aby posiadł zdolności percepcyjne chociażby rocznego dziecka. Wynika to z faktu, że ludzka percepcja jest efektem tysięcy lat ewolucji, zaś myślenie logiczne narodziło się wraz z nowoczesną nauką, co jest osiągnięciem stosunkowo nowym. Z punktu widzenia socjologii pracy umysłowej można powiedzieć, że komputery potrafią rozwiązywać trudne dla umysłu pracownika problemy, takie jak analizowanie dużych ilości stosunkowo jednorodnych danych, prowadzenie skomplikowanych obliczeń lub w końcu żmudne wykonywanie operacji kopiuj-wklej dane z jednego pola w kolejne. Ale zupełnie nie radzą sobie z łatwymi dla ludzi zadaniami, takimi jak połączenie abstrakcyjnych liczb z konsekwencjami biznesowymi czy społecznymi, jakie mogą za sobą pociągnąć.

To nie jedyne wady tego typu rozwiązań. Po głębszym rozeznaniu w praktycznych aspektach wdrażania botów programowych w korporacjach Alex Edlich i Vik Sohoni wskazują, że często przysparzają one mnóstwo kłopotów. Od zbyt długiego czasu instalacji i uruchamiania nadmiernie skomplikowanego oprogramowania przez zmiany na platformach, które obsługują boty programowe (Edlich, Sohoni, 2017). Ponadto boty programowe nie są elastyczne, jak ludzie, dlatego wymagają stałego nadzoru ze strony operatorów. Ich zaprogramowane funkcje pozostają stałe, gdy otoczenie biznesowe, prawne, kulturowe i społeczne dynamicznie się zmienia. Może to być nie lada problemem zarówno w mrówczej pracy biurowej, jak i w zautomatyzowanych kontaktach z klientem przez stronę www.

Zainteresowanie nowymi funkcjami algorytmów komputerowych ze strony biznesu jest całkowicie naturalne i tylko w niewielkim stopniu może być uzasadniane chęcią zastępowania dotychczasowych miejsc pracy. Dużo istotniejszy jest fakt, na który zwracała uwagę już w 2001 roku Shoshana Zuboff, pisząc o dwóch stronach działania technologii, która wymusza upraszczanie wszystkiego, co może 22 być zautomatyzowane — procesów, treści, dokumentów. Jest to konsekwencja 
wdrażania cyfrowej odmiany tayloryzmu. Poza tym komputeryzacja kreuje olbrzymią ilość danych, niezależnie od tego, czy została do tego celu stworzona, czy też nie (Zuboff, 2011, s. 8). A to wymusza stosowanie algorytmów komputerowych, gdyż żaden człowiek nie policzy big data. Co więcej, natłok danych sprawia, że czujemy presję liczenia i kwantyfikowania otaczającego nas świata, a także naszej pracy, nawet jeśli ma ona wymiar wybitnie jakościowy. To sprowadza nas do kolejnego problemu dotyczącego sposobów wartościowania pracy umysłowej.

\section{Czy, a jeśli tak, to jak mierzyć pracę umysłową?}

W Zarzadzaniu w XXI wieku Peter Drucker bezlitośnie podsumował ostatnie 100 lat prób mierzenia i podnoszenia wydajności pracowników umysłowych, konstatując, że „mając na myśli rzeczywiste działania w tym względzie, możemy stwierdzić, że w roku 2000 jesteśmy na tym samym etapie, na którym byliśmy w roku 1900, kiedy wszelkie wysiłki były skierowane na zwiększenie wydajności pracowników fizycznych". Zapewne jest to ocena zbyt ostra, gdyż w tej samej pracy stwierdza Drucker, że wydajność pracy pracowników fizycznych zależy od ich narzędzi i organizacji pracy, a te skutecznie udoskonalano także w przypadku pracowników umysłowych. Zasadnicza różnica, na jaką wskazują Drucker i inni myśliciele od czasów Marksa, to posiadanie przez pracowników umysłowych własnych środków produkcji. Mowa tu o umiejętnościach, wiedzy, doświadczeniu, które są kluczowymi elementami wykonywanej pracy. Idealizując rolę pracowników umysłowych twierdzi Drucker, że powinni być „uważani za aktywa kapitałowe firmy", nie zaś za koszty.

Stąd można wysnuć pierwszy wniosek, że podstawowa forma wartościowania to ta, którą powinien prowadzić sam pracownik, na przykład ewaluacja wewnętrzna - ocena własnych umiejętności, motywacji, kondycji, relacji etc. Kolejnym wnioskiem będzie stwierdzenie, że wydajność pracy umysłowej w zasadniczej mierze zależy od samego pracownika - jego predyspozycji biologicznych, wykształcenia, kapitału społecznego i kulturowego. Wniosek ten będzie tym trafniejszy, im bardziej kreatywny, wymagający i jakościowy jest charakter wytworu końcowego. Podobnie ma się sprawa z oceną efektów tego typu pracy — im bardziej złożony jej charakter, tym większe prawdopodobieństwo, że prawidłowa ewaluacja może być przeprowadzona wyłącznie przez ludzi, z ewentualnym wsparciem narzędzi informatycznych. Przykładem tego typu oceny według Druckera jest na przykład komisja lekarska oceniająca pracę innych lekarzy. Chociaż mamy tu do czynienia także z formą kwantyfikacji, to jest to wielowymiarowa ocena zawierająca zarówno ilościowy, jak i jakościowy aspekt pracy.

W przypadku prostych, powtarzalnych prac o charakterze niematerialnym zaangażowanie umysłowe na wysokim poziomie nie jest wymagane, dlatego rośnie znaczenie stosowanych narzędzi w procesie pracy, podobnie jak ma to miejsce 
w przypadku prostych prac fizycznych. To prowadzi do konstatacji, jaka została postawiona na początku tego tekstu, o nieważności podziału pracy na fizyczną i umysłową, gdyż z punktu widzenia automatyzacji i ewaluacji pracy istotniejszy jest podział na prace o czynnościach rutynowych oraz nierutynowych (Autor, Price, 2013). Jeszcze innym wartościowym analitycznie i opisowo terminem jest „pracownik wiedzy” stworzony przez Petera Druckera. Według rozszerzonej definicji Davenporta, jest to specyficzny typ pracownika umysłowego, którego przedstawiciele „reprezentują wysoki poziom wiedzy specjalistycznej, wykształcenia lub doświadczenia [...] [oraz] zarabiają na życie myśleniem. Ich narzędziem pracy jest umysł, a każdy wysiłek związany z wykonywaniem zawodu ma charakter intelektualny, nie fizyczny" (Daven port, 2007, s. 22-23). To sprawia, że decydując się na pomiar pracy umysłowej, musimy przede wszystkim podjąć decyzję, czy będzie to pomiar pracy rutynowej, czy też nierutynowej (wykonywanej przez pracowników wiedzy). Nie zmienia to faktu, że oba typy pracy umysłowej mogą być i są kwantyfikowane.

Z pewnością sprawy nie ułatwia fakt, że także sama dziedzina zarządzania nie jest w stanie do końca ustalić, czym de facto jest to, co potocznie rozumiemy jako „wydajność”. O problemach z tym terminem pisze Agnieszka Wojtczuk-Turek, zwracając uwagę, że wśród ,wskaźników stosowanych do oceny efektów jednostkowych i organizacyjnych wymienia się: produktywność, wydajność, efektywność, skuteczność" (Wojtczuk-Tu rek, 2016, s. 40). Przy czym w żadnym wypadku nie odnotowano używania jasno zakreślonej definicji, nad czym autorka mocno ubolewa, podsumowując swój przegląd literatury głęboką dezaprobatą dla tej sytuacji: „zarówno w literaturze rodzimej, jak i zagranicznej — poświęconej zagadnieniom opisywanym w niniejszej publikacji — brak jest jednoznacznych i precyzyjnych granic semantycznych w stosowaniu tych terminów" (Wojtczuk-Turek, 2016, s. 40). Ponadto stykamy się z bardzo twardymi sposobami mierzenia wydajności w postaci wskaźników używanych przez urzędy statystyczne. Na przykład GUS w swych publikacjach używa między innymi wskaźników wyliczanych jako:

- iloczyn produkcji sprzedanej przemysłu podanej w cenach bieżących i przeciętnej liczby zatrudnionych;

— iloczyn wartości dodanej brutto podanej w cenach stałych i przeciętnej liczby zatrudnionych $\mathrm{w}$ przemyśle.

Do tego możemy dołożyć klasyczny sposób pomiaru w postaci PKB na głowę mieszkańca danego kraju. Przy czym ciekawostką może być wyliczanie całościowej wydajności konkretnego przedsiębiorstwa jako ilorazu liczby pracowników przez roczne obroty przedsiębiorstwa. Okazuje się, że w tej materii trudno o wydajniejszą firmę niż grupa Alphabet (właściciel Google), która przy zatrudnieniu 78 tysięcy osób generuje ponad 90 miliardów dolarów, co oznacza, że przeciętny pracownik w pojedynkę rocznie wytwarza wartość ponad 1 miliona dolarów. Tego typu proste wyliczenie obarczone jest licznymi wadami, ale może też rzucać zupełnie nowe światło na faktyczną wartość pracy umysłowej w dzisiejszych czasach. Wszak Google to firma oparta praktycznie w stu procentach na pracownikach

24 umysłowych. Przy czym nie sposób nie wspomnieć, że owa praca realizowana 
jest też przez oprogramowanie w formie komputerowych algorytmów. Rodzi się więc pytanie - co naprawdę wyliczamy w ten sposób? Wydajność maszyn czy wydajność ludzi?

Temat ten frapuje badaczy od dawna, jednak w ciągu ostatniej dekady przybrał na sile, między innymi z powodu ustaleń dokonanych przez Erica Brynjolfssona i Andrew McAfee. W przełomowej pracy Race Against The Machine wykazali oni, że chociaż do niedawna zatrudnienie i wydajność rosły razem, to od ponad dekady w USA odnotowuje się znaczące osłabienie zależności między tymi zmiennymi. Jak podaje Brynjolfsson, mediana wynagrodzeń w USA spadła do poziomu z początku lat 90. ubiegłego wieku, przy czym wydajność pracy nieustannie rośnie, a poziom redystrybucji dóbr jasno wskazuje, że bogacą się wyłącznie posiadacze kapitału (Kirkland, 2014).

Tabela 1

Źródła wzrostu gospodarczego w okresie minionych 50 lat i kolejnych 50 lat

\begin{tabular}{|l|c|c|}
\hline \multirow{2}{*}{\multicolumn{2}{|c|}{ Okres wzrostu gospodarczego }} & \multicolumn{2}{|c|}{ Źródła wzrostu gospodarczego (w \%) } \\
\cline { 2 - 3 } & produktywność & siła robocza \\
\hline Minione 50 lat & 1,8 & 1,7 \\
\hline Kolejne 50 lat & 1,8 & 0,3 \\
\hline
\end{tabular}

Źródło danych: Raport Global growth: can productivity save the day in an aging world, 2015, http://www.mckinsey.com/ / media/mckinsey/global\%20themes/employment $\% 20$ and $\% 20$ growth/can $\% 201$ ong $\% 20$ term $\% 20$ global $\% 20$ growth $\% 20$ be $\% 20$ saved/mgi\%20global\%20growth_executive\%20summary_january\%202015.ashx [dostęp: 04.06.2017].

Dane zawarte w tabeli 1 ilustrują kolejny z problemów, jakie napotykamy wówczas, gdy ludzka praca zostaje poddana kwantyfikacji, co sprawia, że zostaje spłaszczona w jej jakościowym wymiarze, aby można ją było porównać z pracą maszyn. Otóż z danych firmy badawczej McKinsey wynika, że w ciągu następnych 50 lat ludzka praca praktycznie przestanie być źródłem wzrostu gospodarczego. Biorąc pod uwagę przytoczone na początku artykułu informacje o lawinowo rosnącej liczbie patentów można odnieść wrażenie, że dane te pomijają jakościowy aspekt ludzkiej pracy w postaci faktycznego wpływu rosnącej liczby wynalazków na wzrost gospodarczy w następnych dekadach. Ponadto - jak już wspomniano każda maszyna, nawet automat wytwarzający dobra fizyczne, wymaga wkładu pracy ludzkiej, czy to w formie pracy żywej czy martwej. Przy czym warto zauważyć, że ta druga podlega ciągłej aktualizacji w pamięci maszyny — wraz z każdą zmianą oprogramowania na nowsze, które dodaje nowe funkcje lub pozwala na sprawne wykonywanie aktualnych. Niestety, praca ta nie jest uwzględniana we wzroście produktywności, jaki prezentują dane od McKinsey. Z jednej strony można zadać pytanie: dlaczego miałoby tak być? Z drugiej, powszechnie przyjmuje się, że najważniejszymi aktywami koncernów są ich logotypy, a raczej ich rozpoznawalność, czyli de facto pamięć i skojarzenia zawarte w ludzkich głowach, wiążące znak graficzny $\mathrm{z}$ określonym produktem. Najdroższe logotypy wyceniane są na kwoty oscylujące w granicach 80 miliardów dolarów — jest to esencja kwantyfikacji pracy jakościowej. 
Wszystko to prowadzi nas do konieczności analizy relacji między wydajnością pracy ludzkiej i pracy maszynowej. Analizę taką podjął Robert Solow, który badał wpływ komputerów na produktywność (na marginesie warto zwrócić uwagę, że nie użył pojęcia „wydajność”. Solowa zainteresował fakt, że dynamika produktywności pracowników w USA spadała wraz z jednoczesnym adaptowaniem przez gospodarkę rozwiązań IT na masową skalę — z 3\% w 1960 roku do 1\% w latach 90. XX wieku. Zjawisko to nazwano paradoksem produktywności Solowa, zaś autor badań doczekał się wielu adwersarzy i kontrdowodów. Przy czym wyniki badań wykonanych przez Solowa opublikowane w 1987 roku nie mogą być i faktycznie nie są adekwatne do dzisiejszej rzeczywistości (A rendt, 2016).

Solow potraktował komputer jak każde inne narzędzie, doszukując się w nim prostej recepty na wzrost produktywności. Wszak w przypadku pracowników fizycznych taka metoda działa - pięciu pracowników z młotami pneumatycznymi wykruszy więcej ton gruzu niż dziesięciu z kilofami. Sęk w tym, że rzeczywistość pracy umysłowej z maszynami jest o wiele bardziej skomplikowana. Powinniśmy mówić o co najmniej dwóch sposobach myślenia o maszynach w pracy umysłowej.

Pierwszym jest spojrzenie na maszyny jak na narzędzia do poprawy nie tylko wydajności, ale także jakości pracy. Spektakularne przykłady to oprogramowanie do pracy grafików, wspierające projektowanie architektów czy inżynierów, w końcu studyjne programy do montażu i obróbki materiałów audio i video. A to tylko wierzchołek góry lodowej. Co więcej, osoby, które nie pracują na co dzień $\mathrm{z}$ tego typu oprogramowaniem, nie rozumieją, jak istotne kryją się różnice pomiędzy ofertami poszczególnych producentów, a nawet pomiędzy poszczególnymi wersjami tego samego oprogramowania. Kryje się w tym podejściu jeszcze jeden paradoks wydajności. Skoro tego typu narzędzia prowadzą do przyspieszenia prac nad materiałami wizualnymi lub dźwiękowymi, to systematycznie powinna maleć liczba pracowników potrzebnych do wykonywania tego typu zadań. Praktyka pokazuje zaś, że dzieje się dokładnie odwrotnie. Ktoś nieprzychylny mógłby przy tym stwierdzić, że koniec końców w skali globalnej jest to dowód na to, że komputery obniżają wydajność, co jest naturalnie absurdem. Dostępność tego typu oprogramowania obniża zarówno koszt wytworzenia materiałów audiowizualnych, jak i próg wymaganego talentu i zaangażowania, aby stworzyć komercyjny projekt na akceptowalnym poziomie. A to sprawia, że na rynku zwiększa się podaż usług w tym zakresie.

Drugi sposób to spojrzenie na maszyny jak na zalgorytmizowane, w pewnym sensie autonomiczne systemy zdolne do samodzielnego wykonywania z góry określonych zadań, czyli wtedy, gdy występują one w roli automatów. Przykładem takich systemów są oczywiście boty programowe, ale nie tylko. Jednym z ciekawszych autonomicznych systemów samodzielnie podejmujących decyzje jest algorytm Spotify, który w ramach usługi Discover Weekly co tydzień prezentuje każdemu użytkownikowi listę nowych utworów dopasowanych do muzycznego gustu. Oprogramowanie największego globalnego serwisu streamingowego z muzyką 26 wykorzystuje trzy różne typy algorytmów. Pierwszym jest collaborative filtering, 
które polega na parowaniu ze sobą użytkowników o podobnym guście muzycznym i wymienianiu między nimi muzyki, której nie mają na swoich playlistach. Drugi to naturalne przetwarzanie językowe (natural language processing) i jego rolą jest analiza recenzji na wybranych portalach i blogach. Ostatni jest najbardziej wysublimowany i sprowadza się do analizy ścieżek audio za pomocą sieci neuronowych. Jest on niezwykle cenny z powodu umiejętności katalogowania utworów, które znajdują się już na platformie Spotify, ale są jeszcze zbyt mało popularne, aby użyć dwóch pierwszych metod (Szczawińska, 2017).

Tak skomplikowany typ pracy umysłowej nie mógł być wykonany ręcznie przy założeniu, że z serwisu muzycznego korzysta około 100 milionów ludzi na całym świecie, a o takim rzędzie wielkości w przypadku Spotify mówimy. Trudno więc w ogóle mówić tu o pomiarze wydajności pracy algorytmów, szczególnie w porównaniu z pracą ludzką. Taka też jest zasadnicza idea takich systemów — zazwyczaj projektowanych na unikatową skalę. Trzeba także pamiętać o wielowymiarowości tego typu projektów, które zanim powstaną są efektem umysłowej pracy niezwykle zdolnych ludzi - jest to często praca unikatowa na skalę światową. Przy czym nie ocenia się owej unikatowości wkładu programistów oraz wynikających stąd zmian społeczno-gospodarczych dla świata muzyki oraz słuchaczy. Znaczenie ich pracy wylicza się na podstawie wynagrodzeń, które otrzymali, lub zysków, które Spotify osiągnęło lub nie. Innymi słowy, praca programistów tego niezwykłego algorytmu jest warta tyle, ile będą w stanie wydać z wynagrodzenia za swoją pracę. Mówiąc prościej — wartość pracy autorów tego algorytmu jest równa ich sile nabywczej wynikającej z wysokości otrzymanego honorarium.

Na drugim krańcu tego kontinuum znajduje się praca ludzi z ludźmi, którą David Autor określi mianem ,nierutynowej interpersonalnej” (Autor, Price, 2013). Jej celem jest budowanie i praca nad relacjami interpersonalnymi, np. w zespole pracowniczym, tak aby uzyskać wyższą wydajność lub w ogóle zrealizować zadanie. Chociaż liczba tego typu miejsc pracy gwałtownie rośnie, to jak pokazują ustalenia Brynjolfssona i McAfee, kompletnie nie widać tego w statystykach produktywności czy wzrostu gospodarczego. Podobne stanowisko prezentuje Geoff Colvin, który w artykule Humans are underrated zwraca uwagę na najnowsze trendy w zatrudnianiu pracowników, a cytuje przy tym wiceprezesa Oracle, który wskazał na empatię jako na „krytyczną umiejętność w XXI wieku” programistów i innych pracowników umysłowych (Colvi n, 2015). Dzisiaj coraz bardziej liczą się umiejętności budowania interakcji społecznych wyrażające się w różnych umiejętnościach, takich jak: kreatywność zespołowa, aktywny udział w burzach mózgu, wrażliwość na różne kultury, przywództwo. Podkreśla przy tym Colvin fakt, że w USA w ciągu ostatnich 50 lat liczba miejsc pracy w edukacji i ochronie zdrowia podwoiła się. Autor ten powołuje się na badania McKinsey Global, które mówią o tym, że kategoria miejsc pracy określana jako interaction jobs jest globalnie najszybciej rosnącą w gospodarkach rozwiniętych. Pomimo to statystyki tego samego instytutu pozostają nieubłagane dla ludzi jako uczestników wzrostu gospodarczego przez kolejne 50 lat (tabela 1). Zupełnie jakby praca skierowana na budowanie relacji społecznych była bezużyteczna z punktu widzenia gospodarki rynkowej. 


\section{Jak mierzyć poziom automatyzacji pracy umysłowej?}

Ustalenia o tym, czy, a jeśli tak, to w jaki sposób warto badać pracę umysłową, nie pozostawiają złudzeń co do tego, że duża część naszej ludzkiej pracy pozostaje ekonomicznie niedowartościowana. Nie zmienia to faktu, że celem niniejszego tekstu jest dążenie do zbadania wpływu automatyzacji pracy na rynek pracy. Wobec tego bazując na pozyskanych zbiorach danych zdecydowałem ograniczyć się do rutynowych prac biurowych, zastrzegając przy tym, że niekoniecznie muszą to być jedyne prace podlegające automatyzacji w przyszłości. Niech za przykład posłuży nowojorskie biuro maklerskie Goldman Sachs, które w ostatnich kilku latach zwolniło prawie 600 maklerów. Na ich miejsca stopniowo zatrudniano inżynierów oprogramowania, którzy zbudowali system algorytmów naśladujących zachowania najlepszych maklerów. Efektem było zastąpienie czterech niezwykle drogich w utrzymaniu maklerów jednym umiarkowanie drogim inżynierem oprogramowania. Już teraz 30\% pracowników Goldman Sachs stanowią właśnie inżynierowie oprogramowania. Na kolejnych stronach pokażę, jak podatne na automatyzację są także miejsca pracy w bankowości.

Zanim do tego przejdę, wrócę do przytoczonego wcześniej badania doktorantów $\mathrm{z}$ uniwersytetu w Bonn. Młodzi badacze postanowili sprawdzić zależność między stosowaniem patentów dotyczących automatyzacji w poszczególnych stanach USA a zmianami na rynku pracy. Jak się okazało, zależności między automatyzacją pracy a pracą rutynową wcale nie są takie oczywiste. Co ciekawe, autorzy badania odnotowali wysoką zależność wcześniej wspomnianych czynników, ale w okolicach roku... 1960. Z czasem zaś wdrażanie patentów automatyzacji w branżach o dużej liczbie zrutynizowanych stanowisk spadało i spada do dziś. Według autorów badania to może być oznaka tego, że automatyzacja, której tak bardzo się boimy, dokonała się już dawno temu. Wszędzie tam, gdzie miała ekonomiczny sens, przynajmniej w materii pracy fizycznej. Co nie mniej zaskakujące, badanie pokazało, że automatyzacja pozytywnie wpływa na poziom zatrudnienia, przede wszystkim gdy dotyczy ono nierutynowych prac, szczególnie w sektorze usług (Mann, Püttmann, 2017). Czyli w obszarze, gdzie są największe problemy z pomiarem i oceną wartości, jaką praca ludzi wnosi do gospodarki.

O swoją pracę wydają się spokojni także pracownicy. Jak podaje badanie Deloitte Global Human Capital Trends przeprowadzane wśród 10 tysięcy liderów działów HR i przedsiębiorstw w 140 krajach, jedynie 20\% respondentów stwierdziło, że spodziewa się redukcji etatów z powodu automatyzacji pracy, a 77\% jest przekonanych, że automaty kompletnie zmienią sposób wykonywania pracy przez ludzi dzięki uwypukleniu ludzkich przewag. Ma to mieć związek z uwolnieniem pracownika od uciążliwych rutynowych zadań i skupieniem się na nierutynowych, kreatywnych celach zawodowych. Badania Deloitte wskazują, że w niedalekiej przyszłości $30 \%$ nowo stworzonych wysoko płatnych zawodów będzie związane ze społeczną stroną biznesu w każdym tego słowa znaczeniu, a więc ich esencją

28 będzie budowanie relacji z innymi ludźmi. 
Jak już wielokrotnie powiedziano, mierzenie poziomu automatyzacji pracy umysłowej rodzi mnóstwo problemów, które mają źródło w samej praktyce tego typu pracy. Dlatego prawdopodobnie nie stworzono ani jednego uniwersalnego wskaźnika, który mierzyłby, w jakim stopniu algorytmy wniknęły w rynek pracy umysłowej. Wynika to z braku analogicznego podejścia, jak w przypadku automatyzacji pracy fizycznej. Nie istnieje na świecie ani jedna organizacja, która skupiałaby producentów oprogramowania automatyzującego ludzką pracę, tak jak ma to miejsce w przypadku producentów automatów do pracy fizycznej. Z tego powodu, że problem ten jest nadal nierozwiązany także od praktycznej strony, nie ustalono nawet, które usługi informatyczne są już automatyzacją pracy, a które tylko ją wspierają.

Oznacza to, że nie ma jednolitego standardu pomiarowego, który pozwoliłby porównać, które gospodarki, gałęzie przemysłu lub przedsiębiorstwa inwestują w cyfrowego „robopracownika” więcej, które zaś mniej. Trudno przy tym oczekiwać, że zmiana sytuacji nastąpi szybko i doczekamy się wskaźnika, jak w przypadku automatyzacji pracy fizycznej, gdzie mierzy się współczynnik liczby robotów na 10 tysięcy pracowników.

W związku z brakiem metodologii pomiarowej postanowiłem sprawdzić zasadność stosowania kilku podstawowych form pomiaru automatyzacji pracy umysłowej w postaci współczynników:

— komputeryzacji,

- informatyzacji,

- algorytmizacji (software robots, czyli boty programowe).

Komputeryzacja to wskaźnik analogiczny do poziomu robotyzacji informujący o fizycznym nasyceniu komputerami społeczeństwa. Według danych przedstawianych przez portal Statista.com, aktualny poziom penetracji komputerów typu desktop jest mocno zróżnicowany w zależności od części świata. Tabela 2 obrazuje też dynamiczny wzrost liczby komputerów per capita w ciągu minionej dekady.

Tabela 2

Poziom penetracji komputerów osobistych w Ameryce Północnej, Europie Zachodniej, Europie Wschodniej (w \%)

\begin{tabular}{|l|c|c|c|}
\hline \multicolumn{1}{|c|}{ Rok } & Ameryka Północna & Europa Zachodnia & Europa Wschodnia \\
\hline 2015 & 76 & 50 & 23 \\
\hline 2010 & 56 & 36 & 13 \\
\hline 2005 & 37 & 22 & 5 \\
\hline
\end{tabular}

Źródło: https://www.statista.com/statistics/203668/pc-penetration-per-capita-in-eastern-europe-since-2000/ [Dostęp: 26.08.2017], https://www.statista.com/statistics/203659/pc-penetration-per-capita-in-north-america-since-2000/[dostęp:26.08.2017], https:// Www.statista.com/statistics/203667/pc-penetration-per-capita-in-western-europe-since-2000/ [dostęp: 26.08.2017].

Zgodnie ze stworzoną wcześniej definicją automatyzacji pracy sam poziom nasycenia komputerami nie powinien być traktowany jak bezpośredni pomiar poziomu automatyzacji pracy umysłowej. Komputer sam w sobie nie jest automatem, który może pracować bez nadzoru. Ale może być nośnikiem oprogramowania, które automatyzuje pracę. 
Drugim wskaźnikiem jest informatyzacja. Jednym z subprocesów informatyzacji jest cyfryzacja, tzn. wprowadzenie do systemów komputerowych danych dotychczas zawartych na analogowych nośnikach, np. na papierze. Jednak cyfryzacja jest pojęciem znacznie węższym od informatyzacji. Od strony teoretycznej informatyzacja, a wraz z nią społeczeństwo informacyjne zostały szczegółowo opisane przez takich autorów, jak Bell czy Castells. Informacjonalizm opiera się na gospodarce, której najważniejszym determinantem jest informacja — jej jakość, czas dostępu do niej oraz jej ilość. Wadą tego pomiaru jest zakres pojęcia informatyzacji, który znacznie przekracza wąską definicję automatyzacji pracy umysłowej. Zaletą jest dość dobra operacjonalizacja tego zagadnienia za pomocą szeregu wskaźników.

Najbardziej rozpowszechnionym wskaźnikiem poziomu zaawansowania społeczeństwa informacyjnego jest Knowledge Index, który stanowi większą część wskaźnika Knowledge Economy Index. Miernik ten pozwala określić, w jaki sposób dany kraj jest w stanie wytwarzać, adaptować i rozpowszechniać wiedzę. Knowledge Index sumuje dane ze zmiennych w postaci edukacji, zasobów ludzkich oraz innowacyjności systemów informacyjnych i komunikacyjnych. Jak nadmieniono wcześniej, problemem tej operacjonalizacji jest zbyt szerokie podejście w stosunku do poszukiwanego przeze mnie wskaźnika. Warto jednak przybliżyć dane zgromadzone przez Bank Światowy, aby mieć możliwość porównywania ich $\mathrm{z}$ innymi, jakie przedstawione są w dalszej części artykułu (tab. 3).

Tabela 3

Piętnaście krajów o najwyższym poziomie Knowledge Economy Index w roku 2012 oraz Polska

\begin{tabular}{|c|c|c|}
\hline Kraj & Knowledge Economy Index & Knowledge Index \\
\hline Szwecja & 9.43 & 9.14 \\
\hline Finlandia & 9.33 & 8.90 \\
\hline Dania & 9.16 & 8.69 \\
\hline Holandia & 9.11 & 9.15 \\
\hline Norwegia & 9.11 & 8.67 \\
\hline Nowa Zelandia & 8.97 & 8.61 \\
\hline Kanada & 8.92 & 8.78 \\
\hline Niemcy & 8.90 & 9.05 \\
\hline Australia & 8.88 & 9.05 \\
\hline Szwajcaria & 8.87 & 8.36 \\
\hline Irlandia & 8.86 & 8.55 \\
\hline Taiwan & 8.77 & 9.12 \\
\hline Stany Zjednoczone & 8.77 & 9.07 \\
\hline Wielka Brytania & 8.76 & 8.81 \\
\hline Belgia & 8.71 & 8.60 \\
\hline Polska (38. pozycja) & 7.41 & 7.51 \\
\hline
\end{tabular}


Średnia Knowledge Index 2012 dla państw Europy Zachodniej wynosi 8.46. W przypadku Ameryki Północnej, reprezentowanej przez Stany Zjednoczone i Kanadę, ten sam współczynnik wynosi 8.97, zaś w przypadku Europy Wschodniej: 6.97, co wskazuje na dużo niższą kulturę techniczną w naszym rejonie Europy. Chociaż widać tu podobną zależność jak w przypadku komputeryzacji, to wskaźnik Europy Zachodniej wyraźnie mniej odbiega od wskaźnika Ameryki Północnej. Co innego Europa Wschodnia, która znacznie gorzej radzi sobie ze społecznym stosowaniem wiedzy informatycznej. Widać tu wyraźny rozstrzał wyników między komputeryzacją i informatyzacją. Trudno też w rozsądny sposób odnieść informatyzację do automatyzacji pracy, gdyż to pierwsze zjawisko opisuje rzeczywistość w sposób ogólny, zaś automatyzacja pracy umysłowej winna skupiać się na konkretnych czynnościach, jakie można poddać algorytmizacji. To prowadzi nas do trzeciego, najbardziej praktycznego czynnika, czyli botów programowych.

\section{Algorytmizacja, czyli software robots (boty programowe)}

Poziom nasycenia tzw. software robots w gospodarce danego kraju może być najciekawszym wskaźnikiem ukazującym poziom automatyzacji pracy umysłowej. Chociaż wdrażanie botów programowych jest wciąż w zalążku, to już widać, że zyski z ich używania mogą być dla organizacji oraz pracowników przełomowe.

Przede wszystkim rozwiązanie to skutecznie likwiduje konieczność poświęcania czasu na żmudne, powtarzalne czynności, które są coraz gorzej opłacane i coraz chętniej podlegają offshoringowi do krajów walczących o inwestycje zagraniczne za pomocą taniej siły roboczej. Według raportu „Robotic Process Automation (dalej będę używał skrótu RPA): The next revolution of Corporate Functions" średni koszt utrzymania pracownika biurowego instytucji finansowej (konkretnie Capgemini) to rocznie około 40 tysięcy dolarów, podczas gdy koszt utrzymania bota programowego wynosi maksymalnie 5 tysięcy dolarów (Capgemini Consulting, 2016, s. 8). Według raportu „Embracing the cognitive era” KPMG boty programowe będą potrafiły uczyć się zachowań ludzkich liderów w wydajności. Następnie wykorzystają je do trenowania mniej wydajnych pracowników, na przykład w formie asystowania podczas organizacji codziennego dnia pracy, podpowiadania sposobów zachowania, w opracowaniu najbardziej wydajnych sekwencji czynności.

Pomiar poziomu inwestycji w boty programowe jest zadaniem niełatwym. Jak już wspomniano, nie powstał żaden wyspecjalizowany wskaźnik pomiarowy ani organizacja, która skupiałaby przedsiębiorstwa oferujące tego typu usługi. Dlatego pozostaje nam śledzenie poszczególnych przedsiębiorstw lub gałęzi gospodarki. Wśród branż najwięcej inwestujących w technologie IT możemy odnaleźć między innymi bankowość, ubezpieczenia, służbę zdrowia. $Z$ racji dostępnych danych korzystam z przykładu bankowości jako branży, w której widoczny jest wpływ systemów RPA (tab. 4). 
Tabela 4

Procentowy udział branż we wzroście wydatków na technologie IT w latach 2015-2020 wg IDC

\begin{tabular}{|l|c|}
\hline \multicolumn{1}{|c|}{ Branża } & Wzrost wydatków na IT (w \%) \\
\hline Profesjonalne usługi & 5,4 \\
\hline Służba zdrowia & 5.3 \\
\hline Bankowość & 5,0 \\
\hline Media & 4,8 \\
\hline Ubezpieczenia & 4,6 \\
\hline Inne & 2,7 \\
\hline
\end{tabular}

Źródło: https://www.idc.com/getdoc.jsp?containerId=prUS42298417 [dostęp: 17.09.2017]

Branża bankowa charakteryzuje się jednym z najwyższych poziomów wydatków na oprogramowanie IT. Zjawisko to łączę z trendami w zatrudnieniu w dwóch największych gospodarkach, w których w bankowości łącznie pracuje około 6 milionów osób. Dane zawarte w tabeli 5 wskazują, jak zatrudnienie w branży kredytowej (utożsamianej z bankową) spadło z 3,11 do 2,86 miliona osób w ciągu raptem 4 lat.

Tabela 5

Zatrudnienie w branży kredytowej

w Unii Europejskiej (w milionach)

\begin{tabular}{|c|c|}
\hline Rok & Liczba zatrudnionych \\
\hline 2011 & 3.11 \\
\hline 2012 & 3.05 \\
\hline 2013 & 2.96 \\
\hline 2014 & 2.89 \\
\hline 2015 & 2.86 \\
\hline
\end{tabular}

Źródło: http://www.ebf.eu/facts_and_figures-2016/\#part2 [dostęp: 17.09.2017]

Instytucje finansowe nie kryją, że inwestycja w oprogramowanie przynosi wyraźne oszczędności w kwestii zatrudnienia. Grupa Citi (tab. 6) sporządziła szczegółowe statystyki wykazujące, jak cyfrowe narzędzia automatyzujące pracę już przynoszą olbrzymie oszczędności finansowe i czasowe. Według prognoz ekspertów z Grupy Citi do 2025 roku w Europie i USA zatrudnienie w bankowości może spaść o blisko połowę. Przyszłością branży jest doradztwo i konsultacje, zamiast obsługi transakcji, gdyż ta będzie odbywać się całkowicie automatycznie. Pokrywa się to z wcześniejszymi wnioskami, jakoby 30\% nowych zawodów miało pojawiać się w miejscach styku interakcji marek z konsumentami, a więc w szeroko pojętym zarządzaniu relacjami społecznymi. Grupa Citi wskazuje, że 65\% kosztów utrzymania banków generuje siła robocza, wobec czego można wysnuć wniosek,

32 że parcie ku automatyzacji będzie konsekwentne. Ale czy przewidywane spadki 
zatrudnienia to stały trend? Gdy automatyzować się zaczną wszystkie banki, to jednocześnie będą one musiały szukać przewagi konkurencyjnej w innych obszarach, np. w budowaniu indywidualnych relacji ze swoimi klientami. To z kolei wiąże się z koniecznością zatrudnienia większej liczby konsultantów zorientowanych na budowanie relacji z klientami. Bieżącą obsługą portfolio i transakcji zajmą się automaty.

Tabela 6

Przewidywane spadki zatrudnienia w branży bankowej wg Citi (w milionach)

\begin{tabular}{|l|c|c|}
\hline \multicolumn{1}{|c|}{ Poziom zatrudnienia } & Stany Zjednoczone & Europa \\
\hline Maksymalny & 2.93 & 3.26 \\
\hline Rok 2015 & 2.57 & 2.89 \\
\hline Prognozowany w 2025 roku & 1.80 & 1.82 \\
\hline
\end{tabular}

Źródło: DIGITAL DISRUPTION How FinTech is Forcing Banking to a Tipping Point s. 80. Citi GPS: Global Perspectives \& Solutions

Jak na tle przedstawionych danych wypadają globalne inwestycje w technologię RPA? Przedsiębiorstwo badawcze HfS Research Ltd. informuje, że już w 2017 roku wydatki na RPA zbliżą się do 0.5 miliarda dolarów, aby przekroczyć 1 miliard w roku 2021 (Fers eht, Snowdon, 2017). Inna firma Grand View Research głosi, że do 2024 roku nakłady na RPA w samych Stanach sięgną nawet 4 miliardów dolarów rocznie. Obie firmy badawcze zgadzają się co do tego, że aktualne wydatki na RPA oscylują w granicach 0,5 miliarda dolarów. Z kolei prognozy obu podmiotów badawczych różnią się znacząco i wskazują jeden pewnik — rynek RPA ma wielki potencjał, który trudno właściwie oszacować. Obie prognozy wskazują na zróżnicowaną, ale w obu przypadkach bardzo dużą dynamikę wydatków na tego typu oprogramowanie. W najgorszym wypadku mowa o podwajaniu ich w ciągu 4-5 lat. Biorąc pod uwagę to, jak znaczący wpływ już dziś RPA wywiera na bankowość, można się tylko domyślać, jak znaczące zmiany wymusi w strukturze zatrudniania innych gałęzi gospodarki, gdy globalne koncerny co najmniej podwoją swoje inwestycje na automatyzację pracy umysłowej.

RPA nieśmiało pojawia się także w Polsce. W styczniu 2018 roku Bank Zachodni WBK ,zatrudnił” boty programowe do obsługi reklamacji składanych przez klientów. Bank pochwalił się, że zaowocowało to skróceniem czasu rozpatrywania wybranych typów reklamacji średnio z dwu dni do kilku godzin. Wśród zalet RPA zarząd banku wskazał korzyści dla obu stron. Klienci czekają zdecydowanie krócej na decyzję reklamacyjną, bank zaś jednocześnie obniża koszty i podnosi jakość swoich usług, gdyż automaty RPA nie popełniają błędów jak ludzie i są zdecydowanie szybsze. Ponadto bank zapewnia, że pracownicy mogą skupić się na bardziej złożonych zadaniach, a więc ich potencjał jest lepiej realizowany. Nie oznacza to, że systemy RPA nie zwolniły ani jednej osoby, gdyż w wydanym komunikacie prasowym skrzętnie ominięto ten temat. Zapewniono jednocześnie, że cała inwestycja zwróci się już w trzy miesiące, co wskazuje na olbrzymi potencjał RPA także w krajach, gdzie koszt siły roboczej jest umiarkowany. Z kolei Alex Edlich 
i Vik Sohoni analizując wdrożenia w największych globalnych firmach piszą o przypadkach, gdy system RPA potrafił w ciągu roku zaoszczędzić ludziom 30 dni pracy w redakcji prasowej czy nawet 60 dni pracy przy tworzeniu miesięcznych raportów finansowych (Edlich, Sohoni, 2017). Przy czym nie precyzują, czy owe dni pracy przełożyły się na zwolnienia, czy też raczej umożliwiły pracownikom uwolnionym od ilościowych zadań zajęcie się jakościowymi aspektami ich pracy.

\section{Podsumowanie}

Pomiar pracy umysłowej oraz jej automatyzacji wykazuje bardzo wyraźny paradoks: chociaż praca umysłowa ma wymiar przede wszystkim jakościowy, to uparcie mierzymy ją ilościowo. Co więcej, współczesna gospodarka dematerializuje się w coraz większym stopniu, dlatego można dojść do zbyt pochopnego wniosku, że ludzka praca traci na znaczeniu w ujęciu globalnym. Obraz tego typu pomiarów jest wyraźnie widoczny w poziomie wynagrodzeń w najbardziej rozwiniętych gospodarkach świata. W ciągu 30 lat najbogatsi Amerykanie zwiększyli swój udział w redystrybucji zysków z działalności gospodarczej z 17\% do $43 \%$, przy czym zajmują też 75\% zysków kapitałowych (Piketty, 2014). Te dane wskazują, że okno pozwalające przebijać się nowym podmiotom na globalnym rynku wyraźnie się zamyka. Thomas Piketty dochodzi do wniosku, że pracować nie opłaca się tak bardzo jak inwestować kapitał - ta druga forma zarabiania jest zdecydowanie bardziej opłacalna. Argumenty Piketty’ego uznaje także Paul Krugman: ,[...] od czasu, gdy rozpoczął się kryzys finansowy, zyski korporacji poszybowały w górę, podczas gdy w wynagrodzeniach — w tym osób wysoko wykształconych - nastąpiła stagnacja" (K rug man, 2014). To wszystko podpowiada nam pewne wyjaśnienie pytania: $\mathrm{z}$ czego wynika pogarszająca się według przedstawionych statystyk pozycja przeciętnego pracownika? Wiele wskazuje na to, że kapitał zyskuje kosztem pracy, zaś jednym z powodów tej sytuacji jest fakt nieumiejętnego mierzenia pracy umysłowej.

Problemów w pomiarze przysparza właściwie każdy aspekt współczesnej pracy umysłowej. Osią problemu jest napięta relacja ludzi i maszyn, w której jakościowy aspekt ludzkiej pracy przeciwstawiany jest ilościowej sile obliczeniowej komputera. Ilościowy sposób pomiaru stawia ludzi na z góry przegranej pozycji, zaś wyliczenie społeczno-gospodarczego wpływu pracowników jakościowych nie jest priorytetem dla jakiegokolwiek pracodawcy. Źródeł tej sytuacji należy doszukiwać się w miernikach wydajności, które powstały w czasach społeczeństwa industrialnego, dzisiaj zaś wydają się w coraz mniejszym stopniu spełniać swoją funkcję. Chociaż praktycznie wszystko podlega teraz wycenie rynkowej, nie oznacza to automatycznie, że wycena ta jest przeprowadzona należycie. Tym samym należy stwierdzić, że pytanie, czy warto mierzyć pracę jakościową, jest prawie tożsame

$34 \mathrm{z}$ pytaniem, jak to robić. 
Zaproponowane przeze mnie narzędzia do badania poziomu automatyzacji pracy niewątpliwie pozostawiają wiele do życzenia i należy je traktować raczej jako próbę sprowokowania do dyskusji o tym, czy, a jeśli tak, to w jaki sposób mierzyć, niż jako gotowe narzędzia pomiarowe. To, czego możemy być pewni, to fakt, że automatyzacja pracy ma wpływ na rynek pracy. Ocena tego wpływu zależy od gałęzi gospodarki, perspektywy czasowej, a także stanowiska pracy, jakie zajmuje konkretny pracownik. Przytoczone przeze mnie dane na temat sektora bankowego nie są zbyt optymistyczne, przy czym nie powinno się traktować ich jako ostatecznie rozstrzygających. Z kolei najnowsze badanie doktorantów z Uniwersytetu w Bonn pokazuje, że w długim okresie automatyzacja pracy może być korzystna nie tylko dla pracodawców, ale także dla pracowników - i to w skali potężnego kraju i gospodarki, jakimi są Stany Zjednoczone. Niestety, w tym momencie nie jesteśmy w stanie odpowiedzieć na najważniejsze pytania badawcze: jak automatyzacja pracy wpływa na jakość pracy ludzi oraz jak automatyzacja pracy wspiera wydajność pracowników umysłowych, w końcu — jakie są faktyczne korzyści dla gospodarki z pracy umysłowej wysoko kwalifikowanych pracowników.

\section{Bibliografia}

Abbatiello A., Boehm T., Schwartz J., Chand S., 2017: No-collar workforce: Humans and machines in one loop - collaborating in roles and new talent models. https:// www2.deloitte.com/insights/us/en/focus/tech-trends/2018/no-collar-workforce.html [dostęp: 20.12.2017].

Arendt Ł., 2016: Paradoks Solowa i determinanty wdrożenia technologii informacyjnych i telekomunikacyjnych. http://gospodarkanarodowa.sgh.waw.pl/p/gospodarka_narodo wa_2016_01_02.pdf [dostęp: 20.12.2017].

Arthur B., 2011: The second economy. http://www.mckinsey.com/business-functions/ strategy-and-corporate-finance/our-insights/the-second-economy [dostęp: 04.06.2017].

Arthur B., 2017: Where is technology taking the economy? https://www.mckinsey.com/ business-functions/mckinsey-analytics/our-insights/where-is-technology-taking-theeconomy?cid=other-eml-alt-mkq-mck-oth-1712 [dostęp: 20.12.2017].

Autor D.H., Price B., 2013: The Changing Task Composition of the US Labor Market. https://economics.mit.edu/files/11661 [dostęp: 04.06.2017].

Beniger J., 1986: The Control Revolution. Cambridge, Massachusetts, and London, England: Harvard University Press.

Brynjolfsson E., McAfee A., 2011: Race Against The Machine: How the Digital Revolution is Accelerating Innovation, Driving Productivity, and Irreversibly Transforming Employment and the Economy. http://b1ca250e5ed661ccf2f1-da4c182123f5956a 3d22aa43eb816232.r10.cf1.rackcdn.com/contentItem-5422867-40675649-ew37 tmdujwhnj-or.pdf [dostęp: 04.06.2016].

Capgemini Consulting, 2016: Robotic Process Automation (RPA). The next revolution of Corporate Functions. https://www.fr.capgemini-consulting.com/resource-file-access/ 
resource/pdf/robotic_process_automation_the_next_revolution_of_corporate_fun ctions_0.pdf [dostęp: 18.09.2017].

Castells M., 2007: Społeczeństwo sieci. Przeł. M. Marody, K. Pawluś, J. Stawiński, S. Szymański. Warszawa: Wydawnictwo Naukowe PWN.

Colvin G., 2015: Humans are underrated. http://fortune.com/2015/07/23/humans-areunderrated [dostęp: 20.12.2017].

Davenport T.H., 2007: Zarzadzanie pracownikami wiedzy. Przeł. M. Lany. Kraków: Wydawnictwo Wolters Kluwer.

Drucker P., 2000: Zarządzanie w XXI wieku. Przeł. B. Kacprzyńska. Warszawa: Wydawnictwo MUZA SA.

Edlich A., Sohoni V., 2017: Burned by the bots: Why robotic automation is stumbling. https://www.mckinsey.com/business-functions/digital-mckinsey/our-insights/digitalblog/burned-by-the-bots-why-robotic-automation-is-stumbling [dostęp: 20.12.2017].

Ferseht P., Snowdon J., 2017: The Robotic Process Automation market will reach $\$ 443$ million this year. https://www.horsesforsources.com/RPA-marketsize-HfS_061017 [dostęp: 21.09.2017].

Florida R., 2004: The Rise of The Creative Class. New York: Basic Books.

Flusser V., 2015: Ku filozofii fotografii. Warszawa: Wydawnictwo Aletheia.

Ghose R., Sandeep D., Shirvaikar A., Horowitz K., Tian Y., Levin J., H o S., 2016: DIGITAL DISRUPTION How FinTech is Forcing Banking to a Tipping Point. Citi Group.

Grand View Research, 2016: Robotic Process Automation (RPA) Market Analysis By Services (Professional Services, Training Services), By Organization (Small And Medium, Large Enterprises), By Application (BFSI, Telecom \& IT, Healthcare, Retail, Manufacturing) And Segment Forecasts To 2024. http://www.grandviewresearch. com/industry-analysis/robotic-process-automation-rpa-market [dostęp: 21.09.2017].

Kerckhove D. de, 2009: Mapowanie mediów. W: A. Maj, M. Derda-Nowakowski, red.: Kody McLuhana. Topografia nowych mediów. Katowice: Wydawnictwo Naukowe ExMachina.

Keynes J.M., 1930: Economic Possibilities for our Grandchildren. https://assets.aspe ninstitute.org/content/uploads/files/content/upload/Intro_and_Section_I.pdf [dostęp: 20.12.2017].

Kirkland R., 2014: The Great Decoupling. http://www.mckinsey.com/insights/public sector/the_great_decoupling [dostęp: 26.10.2014].

KPMG, 2016: Embracing the Cognitive Era. https://assets.kpmg.com/content/dam/kpmg/ pdf/2016/03/embracing-the-cognitive-era.pdf [dostęp: 20.12.2017].

Krugman P., 2014: Why We're in a New Gilded Age. The New York Review of Books. http://www.nybooks.com/articles/archives/2014/may/08/thomas-piketty-new-gildedage/ [dostęp: 26.10.2014].

Krzysztofek K., 2012: Koniec pracy, jaka znamy. Maszynopis.

Landes D., 2000: Bogactwo i nędza narodów. Warszawa: Wydawnictwo MUZA SA.

Lemański A., 2015: Rola pracownika XXI wieku: czy maszyny zastapia ludzi? Konkurencja czy kooperacja? „Humanizacja Pracy”, nr 3 (281), s. 153-165. http://www. humanizacja-pracy.pl/witryna/doc/Humanizacja32015.pdf [dostęp: 04.06.2017].

Mann K., Püttmann M., 2017: Benign effects of automation: New evidence from patent texts. http://voxeu.org/article/benign-effects-automation-new-evidence [dostęp: 20.12.2017]. 
Manyika J., Woetzel J., Dobbs R., Remes J., Labaye E., Jordan A., 2015: Global growth: can productivity save the day in an aging world? http://www.mckinsey. $\mathrm{com} / \sim /$ media/mckinsey/global\%20themes/employment\%20and\%20growth/can\%20 long $\% 20$ term $\% 20$ global $\% 20$ growth $\% 20$ be $\% 20$ saved $/ \mathrm{mgi} \% 20$ global $\% 20$ growth executive\%20summary_january\%202015.ashx [dostęp: 05.08.2017].

Mariański J., 2015: Władysława Jachera koncepcja pracy ludzkiej. W: B. Pactwa, U. Swadźba, M. Żak, red.: Praca - więź-integracja. Wyzwania w życiu jednostki $i$ społeczeństwa. T. 1. Katowice: Wydawnictwo Uniwersytetu Śląskiego, s. 27-50.

McLuhan H.M., 2004: Zrozumieć media: przedłużenia człowieka. Przeł. N. Szczucka. Warszawa: Wydawnictwa Naukowo-Techniczne.

Pasquinelli M., 2011: Maszynowa wartość dodatkowa a praca informacji: uwagi o ekonomii politycznej maszyny Turinga. Przeł. K. Szadkowski. W: J. Sowa, red.: Wieczna radość. Ekonomia polityczna społecznej kreatywności. Warszawa: Wydawnictwo Fundacja Nowej Kultury Bęc Zmiana, s. 131-158.

Piketty T., 2014: Capital in the Twenty-First Century. London, Cambridge: Belknap Press/Harvard University Press.

Pinch T.J., Bijker W.E., 1993: The Social Construction of Facts and Artifacts: Or How the Sociology of Science and the Sociology of Technology Might Benefit Each Other. In: T.J. Pinch, T.P. Hughes, W.E. Bijker, eds.: The Social Construction of Technological Systems. Cambridge, Massachusetts London, England, s. 17-50.

Schwartz J., Collins L., Stockton H., Wagner D., Walsh B., 2017: Deloitte Global Human Capital Trends: Rewriting the rules for the digital age. https://www2. deloitte.com/content/dam/Deloitte/global/Documents/About-Deloitte/central-europe/ ce-global-human-capital-trends.pdf [dostęp: 20.12.2017].

Szczawińska M., 2017: Jak Spotify dobiera utwory do playlisty Discover Weekly? https://rms.pl/baza-wiedzy/2726-jak-spotify-dobiera-utwory-do-playlisty-discoverweekly [dostęp: 20.12.2017].

Szpunar M., 2012: Nowe-stare medium. Internet między tworzeniem nowych modeli komunikacyjnych a reprodukowaniem schematów komunikowanie masowego. Warszawa: Wydawnictwo IFiS PAN.

Weiss S., Indukhya N., 1998: Predictive Data Mining. A practical guide. San Francisco: Morgan Kaufmann.

Wojtczuk-Turek A., 2016: Wspieranie produktywności pracowników wiedzy. Warszawa: Wydawnictwo Naukowe PWN.

Zuboff S., 2001: Automate/Informate: The Two faces of Intelligent Technology. http:// layoftheland.net/archive/web/mis-575/course_docs/topic_5/zuboff.infomate.pdf [dostęp: 21.08.2017].

\section{Netografia}

Ebf.eu

Idc.com

Knoema.com

Statista.com 